\title{
Päike, kuu ja tähistaevas tšuktši mütoloogias ning taevakehade seostest ohverdamistega
}

Ülo Siimets

\begin{abstract}
Teesid
Käesolevas artiklis antakse lühike ülevaade põhiliselt tšuktši müütidest, kujutelmadest ja uskumustest taevakehade kohta 19. sajandi lõpul ja 20. sajandi algul. Tšuktši tähistaevas on seotud nende põhielatusala põhjapõdrakasvatusega. Tšuktšid on üks väheseid Siberi rahvaid, kellel on säilinud oma usund. Nagu paljude rahvaste, nii ka Kaug-Põhja rahvaste ja tšuktšide juures on päike, kuu ja tähed personifitseeritud. Välja tuuakse ka tšuktšide kujutelmade sarnasused teiste rahvaste uskumustega. Tänini kasutavad sealsed põhjapõdrakasvatajad tähtsamate ohverdamise juures mõne tähtkuju või planeedi arvatavat abi või mõjujõudu (näiteks ohverdavad täiskuu ajal). Tšuktšide arvates on taevas tähtsaim tegelane päike. Nad kirjeldavad teda kui eraldi olevust (vaъrgъn). Peale tema kuuluvad eriliste (ülemiste) olendite hulka Looja, Koit, Seniit, Keskpäev ja Põhjanael. Kuu on tšuktši mütoloogias inimene-olend. Ta on nagu päikese ketlja (paha vaim). Mitmete tähtedega (nt Põhjanaela ja Orioniga) seotud tšuktši müüdid on väga sarnased teiste rahvaste omadele.
\end{abstract}

Märksõnad: astraalmütoloogia, kuu, ohverdamine, põhjapõdrakasvatus, päike, taevakehad, tšuktši usund, tähtkujud

Maa sõltumine taeva- ja ilmastikunähtustest on inimkonnale erilise tähtsusega, sest just päikese ja kuu, öö ja päeva, tuule ja sademete ning pinnase kooseksisteerimine loob elu ja soojuse ning annab igapäevase toidu. Üle kõige on üks taevas. Pimedasse taevasse ilmuvad tähed, nende tohutud hulgad sunnivad mõtlevat olendit vastama küsimustele, milline on maailma olemus ja päritolu ning mis on elu eesmärk. Selle peale mõtlesid inimesed juba ammustel aegadel ja jäävad mõtlema ka tulevikus. Nendele küsimustele on püütud vastata igal ajajärgul vastavalt teadmiste tasemele.

Eri aegadel on maailma valitsenud erinevad jumalused, ent päikest on kogu inimkonna ajaloo vältel peetud kõige algeks. Maa süm-

http://haldjas.folklore.ee/tagused/nr30/siimets.pdf 


\section{Ülo Siimets}

bolid täiendavad taeva omi ja esindavad Suurt Ema (Maaema), kes viljastub vihmast ja sünnitab taimed, mis toidavad teisi elusolendeid. Maaema teema ulatub mütoloogias tuhandete aastate taha. On leitud suurerinnalisi, taasloovas ja toitvas rollis naist kujutavaid savikujukesi, mis pärinevad ajast üle 20000 aasta enne Kristuse sündi. Mered, järved ja jõed on uskumuste järgi üks osa kõiksuse heldekäelistest andidest ning nad jagavad maaga tema naiselikke, toitvaid omadusi. Et taevas on päikese, kuu ja tähtede asupaik, on taevas olnud alati ühenduses loovate jõudude ja loojajumalatega.

Käesolevas artiklis antakse lühike ülevaade põhiliselt tšuktši müütidest, kujutelmadest ja uskumustest taevakehade kohta 19. sajandi lõpul ja 20. sajandi algul. Kui on leitud sarnasusi tšuktšide ja teiste rahvaste müütidega, on need artiklis välja toodud. Kasutatud on tšuktšide uurija Vladimir Bogoraz-Tani tähelepanekuid, Andres Kuperjanovi raamatut Eesti taevas. Uskumusi ja tõlgendusi (Kuperjanov 2003) ja autori 1971. aastal Tšuktšimaal elades peetud päeviku materjale. Kui on leitud seoseid mõne taevakehaga, on võrdluseks on tutvustaud ka huvitavaid fakte raamatust Mütoloogiad kogu maailmast (McKenzie \& Prime \& George \& Dunning 2002).

Nagu paljude rahvaste, nii ka Kaug-Põhja rahvaste ja tšuktšide juures on päike, kuu ja tähed personifitseeritud. Nad on nagu elus, aga mingit teistsugust päritolu kui muud olendid. Samas pöördutakse palvetes ja loitsudes ikka nende poole. Väga paljud rahvad ohverdasid veel lähiminevikus või ohverdavad praegugi nende auks.

Tšuktšide juures põhjapõdrakarjas olles panin tähele, et esiteks on kõik nende põhilised ohverdamised seotud põhjapõtradega. See on ka arusaadav, sest kogu nende elu sõltub põhjapõdrakarja heaolust. Teiseks kasutati tähtsamate ohverdamiste puhul mingi tähtkuju või planeedi arvatavat abi või mõjujõudu (näiteks ohverdati täiskuu ajal). Olen selliseid ohverdamisrituaale ise näinud ja ka kuulnud tšuktšide sellekohaseid selgitusi. Ohverdamisel on kasutatud kuu, Koidutähe või mõne muu taevakeha arvatavat mõju.

\section{Päike}

Paljudes kultuurides üle kogu maailma käsitletakse päikest meheliku alge ning ühtlasi valguse ja soojuse kehastajana. Päike oma igapäevase tõusu ja loojumisega sümboliseerib surma ja taassündi. 
Päike soojendab maad ja küpsetab vilja. Kui räägime päikesest või päikesejumalast, viib esimene mõte meid kindlasti Egiptuse päikesejumala Ra juurde. Igal hommikul alustab ta oma teekonda üle taeva, saades võitu pimeduse kaosest ja hävitades kurja. Ajalootundidest mäletame, et Egiptuse vaarao Amenhotep IV kuulutas ainsaks jumalaks Atoni (päikese). Vanas Egiptuses oli Päikesejumal Ral kolm kehastust: hommikul sõnnikumardikas Hephri, päeval pistrikupeaga Ra ning õhtul loojuvat õhtupäikest kehastav inimese või jäära peaga Atum. Igal hommikul pidi päike võitlema maojumala ehk kaose kehastaja Apophisega (McKenzie \& Prime \& George \& Dunning 2002: 34).

Sumeri päikesejumal Utu oli pimeduse ja kurjuse vaenlane, kes ajas tõved minema oma tiibades peituva ravijõuga. Ta oli ka õiglusejumal. Hiljem sai ta nimeks Šamaš, mis tähendab akadi keeles päikest (McKenzie \& Prime \& George \& Dunning 2002: 24).

Keldi valguse- ja päikesejumal Lug oli üks väheseid keldi jumalaid, keda austati Iirimaast kuni Hispaaniani. Tema nimi tähendab tõlkes 'särav'. Lug oli sõdalane, võlur ja kõigi käsitööde valitseja. Keltidele sümboliseeris tuli päikest. Nad pühitsesid aastaaegade vaheldumist nelja suur pidustusega. Neist tähtsamad tseremooniad olid samhain ja beltine, millega tähistati talve ja suve tulekut. Ülejäänud kaks - imbolc ja lugnasad - korraldati veebruaris ja augustis. Ka skandinaavlastel olid sellised pühad ja neilegi oli tähtsaim talve alguse tähistamine, mis kestis mitu päeva. Seda nimetati talveööde pidustusteks. Antiikautorite kirjutistes on juttu keldi pidustustest, eriti samhainiga seotud viljakusriitustest ja inimohverdustest. Jumal Teutatese auks ohvreid uputati ja Taranise lepitamiseks põletati neid korvides (McKenzie \& Prime \& George \& Dunning 2002: 69, 72; vt ka Ó hÓgáin 2004).

Kõige koletuslikumad ohverdamised päikesele on pärit Ameerikast. Eriti veriseid ohverdamisi viidi läbi inkade ja asteekide juures. Inkade impeeriumi tähtsaimaks kultuseks oli päikesekultus. Selle usundi keskuseks oli Coricancha tempel Cuzcos. See oli kuue ruumiga tempel, kus üks ruum oli pühendatud Päikesele-Intile, keda peeti inkade sugupuu jumalikuks meessoost esindajaks. See ruum oli rikkalikult kullaga kaetud ja seal asus Inti kuju. Peamine pidustus tema auks oli Inti Raimi. Teine ruum templis oli kaunistatud hõbedaga ja pühendatud kuule. Kuujumala nimi oli Killa ja ta oli inkade naissoost jumalik esivanem. Kolmas ruum oli äikesejumal Illapa jaoks ja neljas jumal-looja Viracochale. 


\section{Ülo Siimets}

Uue inka trooniletõusmisel pidid kõik Tawantinsuyu (Nelja Ilmakaare riigi) neli provintsi saatma pealinna ohvriande. Nendeks olid laamad, alpakad, kangad väärismetallid ja ka lapsed. Inka võttis kingitusi vastu Cuzco peaväljakul. Lapsed käisid kaks korda ümber Looja, Päikese, Kuu ja Äikese kuju. Siis kutsus Inka provintside preestrid ja lasi neil jagada ohvriannid neljaks osaks vastavalt inkade valduste neljale piirkonnale. Lastel kästi linnast lahkuda ja nad rändasid mägedes asuvate pühapaikade (huacade) juurde. Seal laps ohverdati. Tema süda rebiti rinnust ja huaca pealispind määriti verega.

Asteekide mütoloogia loomisjumalate olulisimad teod on seotud päikese loomisega. Usuti, et hoidmaks päikest tema taevasel teekonnal, seega säilitamaks asteekide universumi terviklikkust, oli vaja päikest pidevalt inimverega toita. Nii olid Tonatiuhi (päikese) ja Huitzilopochtli (päikesejumala sõja) kultused asteekide impeeriumi alustoed. Ohverdatavate muretsemine oli sõdalaste ülesanne. Kui ei olnud piisavalt vange või vabatahtlike, pidid sõdurid ise oma elu jumalatele ohverdama. Päikese isu vere järele oli ilmselt piiritu. Suures templis ohverdati ka lapsi. Igal aastal tapeti asteekide rituaalsetel ohverdustel ca 20000 inimest. Asteekide kalendris oli keskne koht päikesel. Aasta koosnes 18 kuust (McKenzie \& Prime \& George \& Dunning 2002: 129-136). Inimeste ohverdamises pole kõik uurijad siiski ühel meelel, vastupidiseid seisukohti on kajastanud näiteks Tarmo Kulmar (2004).

Kreeklaste päikesejumal Apollon oli pimeduse võitja, teda kujutati tihti piltidel ja mosiikidel mehena, kelle pea oli leekidest ümbritsetud.

Keskaegse Euroopa alkeemikute seas valitses teadmine, et päike on oma sisemise tulega algainena peidus igas aines. Seetõttu kuulus päikesemärk vabamüürlaste sümbolite hulka.

Ka tšuktšide tähtsaim tegelane taevas on päike. Ta ei ole nii verejanuline kui Ameerika päikesejumalad. Vladimir Bogoraz-Tan kirjutab, et tšuktšid kirjeldavad päikest kui eraldi olevust (vaъrgъn). Peale tema kuuluvad eriliste (ülemiste) olendite hulka Looja, Koit, Seniit, Keskpäev ja Põhjanael.

Päikest kujutatakse läikivates (kas vasksetes või kuldsetes) riietes mehena, kes sõidab taevas ringi koerarakendi või põhjapõtradega. Põhjapõtradel on kuldsed või vasksed sarved. Ta lasi taevast alla ühe oma kiirtest, võttis naiseks maise tüdruku ja tõmbas ta kiirega üles taevasse. Igal õhtul pöördub päike tagasi oma naise juurde. Naise nimi on Kavra-nga (eesti keeles 'Ringi käiv naine') 
(Bogoraz-Tan 1939: 25). Sellest nimest võib järeldada, et tšuktšidel elab päike koos naisega nii, nagu elavad rändkarjakasvatajad - ümberpaigaldatavas kojas. Karjakasvatajad-tšuktšid muudavad pidevalt oma eluaseme asukohta.

Jumal kinkis osa oma põhjapõtradest inimestele. Päikesekarjast on pärit valged põhjapõdrad. Kirjud, hallid ja pruunid põhjapõdrad on pärit maa alt, "karusnahku sünnitavalt maalt" (Oviri-nutenut). See maa asub kohas, kus taevas ja maa kohtuvad. Seal on maa sees suur auk ja sellest august jooksevad pidevalt välja põhjapõdrad, kes põgenevad huntide eest.

\section{Kuu}

Ka kuu sümboliseerib surma ja taassündi, seda tänu oma igakuisele kasvamisele ja kahanemisele. Kuu valitseb vete üle, pannes vetepinna tõusma ja mõõnama.

Sumerite kuujumalanna nimi oli Nanna. Uri linnas oli suur tsirkuraat, mille tipus asus kuujumalanna Nanna tempel. Linnaelanikud tõid Nannale kingitusi ja asetasid need kivist ohvrilaudadele. Nad annetasid ka väikesi palvetavate inimeste kujutisi, mis paigutati Nanna kuju kõrvale, et nad annetajate eest pidevalt palvetaksid. Templites ohverdati ka loomi. Valitsejad korraldasid Nanna altaril regulaarselt tseremooniaid, et peletada kurjust ja tagada endale pikk eluiga. Üksnes ülempreester võis siseneda templi kõige pühamasse kambrisse, mis oli Nanna eluase. Hiljem sai Nanna akadi nime Sin. Tema sümboliks on noorkuu (McKenzie \& Prime \& George \& Dunning 2002: 25-27).

Egiptuses oli kuujumal Thot päikesejumal Ra saadik, asetäitja, vesiir. Müüdis trooni pärast kemplevate jumaluste Horose ja Sethi tülis on Thot kohtunik. Seth meelitas Horose oma majja, kus üritas astuda temaga seksuaalvahekorda, et tõestada Horose ebamehelikkust. Horosel õnnestus Sethi seeme oma kätte püüda. Horose ema Isis võttis natukene poja seemet ja puistas seda salatilehtedele, Sethi lemmiktoidule, mille Seth seejärel ära sõi. Kui Seth ilmus jumalate nõukogu ette oma võiduga kelkima ja kuningavõimu nõudma, käskis kohtunik Thot ilmuda Sethi ja Horose seemnetel. Sethi seeme vastas meresügavusest, Horose oma aga muutus kuukettaks, mis kasvas välja Sethi peast. Thot võttis kuuketta ja paigutas jumaliku sümbolina enda pähe. 


\section{Ülo Siimets}

Palvete ja rituaalidega võis jumalaid kutsuda templisse skulptuuri või püha looma. Kuujumala pühadeks lindudeks olid iibised, kelle palsameeritud kehasid on leitud paljudest haudadest. Thoti kujutati ka paavianinäolise mehena (McKenzie \& Prime \& George \& Dunning 2002: 32, 34, 38-39).

Inkade müütides oli kuu (Killa) algul eredam kui päike. See tegi päikese armukadedaks ja ta viskas kuule tuhka näkku, mistõttu kuu muutus tuhmimaks - selliseks, nagu ta praegu on (McKenzie \& Prime \& George \& Dunning 2002: 129).

Tšuktši mütoloogias on kuu inimene-olend. Tal on tšuktšide maailmas päikesele vastupidine positsioon. Ta on nagu päikese ketlja (paha vaim). Tema poole pöörduvad šamaanid ja muud loitsijad. Kuu abil on võimalik teostada oma kurje plaane: panna teistele peale nõidusi või needusi. Kuud ei tohi liiga kaua vaadata, sest siis lähed hulluks või viiakse sind maa pealt hoopis mujale, näiteks kuu peale. Kuul on tšaad (eesti k 'viskerihm, lasso'), millega ta püüab inimese kinni ja tirib enda juurde. Ta on sellega kinni püüdnud juba tüdruku või poisi või mõlemad ja tirinud enda juurde kuu peale. Et Kuul on $t s ̌ a a d$, ohverdatakse talle tšuktšide pidustustel rihmatükke (Bogoraz-Tan 1939: 22-23).

See müüdi variant, et kuu peal on inimene, on levinud nii Eestis kui ka mujal põhjamaades (Kuperjanov 2003: 69).

Kuu kasutamine maagiliste loitsude mõju tugevdajana on levinud laialdaselt tšuktšide juures. Ühes legendis kutsub vana šamaan Jelöpa endale kuu appi. Muidu ei jätkunud šamaanil jõudu karistada vaenlast, kes oli põhjapõdrakarja omanik ja tahtis tema kui vana mehe karja juurest minema ajada. Sel juhul oleks ta tundras ära külmunud või lihtsalt nälga surnud. Nüüd ei jäänud šamaanil muud üle, kui paluda loitsude abil oma vaenlasele surma. Toon sellest loost katkendi.

Rituaali läbiviimiseks oli šamaanil vaja täiskuu abi. Muud tal siis teha ei jäänudki, kui vaikselt omaette kiruda ja oodata. Lõpuks saabus täiskuuaeg. Taevas oli selge. Tähed sirasid ja kuu oli taevas nagu suur kollane ketas. Śamaan oli juba varakult alustanud oma rituaalidega pühas ehk "pimedas" jarangas. Tema bubini põrin kaikus raevukalt tundra kohal ning kuulda oli tema kriiskeid ja karjeid. Tavaliselt olid šamaani toimingutest osa võtnud ka teised, aga seekord viis ta rituaali läbi täiesti üksi. Inimesed kõrvaljarangades ei saanud maga- 
da.Aeg-ajalt muutusid karjed hästi kiljuvaks, aegajalt oli kuulda tumedat pobinat. Sama oli ka bubini põristamisega. Ka selle tagumine käis lainetena. Vahel oli kuulda kiiret peenikest kôla, vahel kostsid harvad tumedad mütsud.

Keskööl vaikis trummipõrin. Üks karjustest, kes enne ei julgenud välja minna, läks õue vett laskma. Kui ta oli põie tühjendanud, kuulis ta šamaani jaranga juurest hääli. Ta piilus oma jaranga tagant ja nägi oma imestuseks neljakäpakil kõndivat Jelöpalit. Mees oli täiesti alasti. Ainsaks riietusesemeks oli šamaanil loomade peanahkadest tehtud müts. Jelöpal kõndis neljakäpakil tundrasse otse kuu suunas.

Karjus ei olnud kõikidest sõnadest aru saanud, aga põhimõte oli selline:

"Oo kuu, kuu. Sina, kes sa valitsed ööd.

Sina, kes sa oled suuteline pimeduse katkestama, aita mind. Sa näed, kuidas ma alandlikult rooman sinu ees.

Mul ei ole saladusi sinu ees, ma näitan sulle täielikult oma keha. Aita mind.

Aita mul saada jagu vaenlasest. Ta on alandanud mind. Ta on teinud mu teiste ees naeruväärseks. Halasta mulle. Ma olen sulle alati ohvreid toonud ja kui sa mind aitad, siis toon ma neid ka edaspidi.

Aita leevendada minu raevu. Tee nii, et minu vaenlane sureks" (vt pikemalt Siimets 2003: 231-245).

Mõni nädal pärast rituaali läbiviimist vaenlane surigi ja šamaan oli jälle kõige tähtsam isik põhjapõdrakarjuste juures

Ka Eestis oli varasemates uskumustes kuu isikustatud. Ta oli näiteks üks Tähemõrsja kosilastest. Aga seda näitab kas või komme, et esimest korda noorkuud nähes teda teretatakse, palutakse temalt raha, jõukust, soovide täitumist. Piisab, kui noorkuud nähes taskus münte kõlistada või kuule raha näidata. Ka pöörduti kuu poole tavaliselt loitsuvormis. Eesti kuuloitse on üles kirjutatud kroonikatest tänini. Erinevalt paljudest nõidussõnadest, mida keegi enam ei mäleta või mida teab eriline teadja, on need ravimisel ikka veel kasutusel (Kuperjanov 2003: 74).

Sama olukord on ka tšuktšide juures. Noored tšuktšid ei tea enam loitsude tähendusi või ei taha sellest rääkida. Kui küsisin, miks sa seda või teist rituaali läbi viid või neid loitse lausud, vastasid nad: et oleks parem. Paljud šamaanide raviseansid toimusid täiskuu ajal. 


\section{Ülo Siimets}

Kindlasti viidi neid läbi ka muul ajal, aga tähele panime ehk kuulsime Vaegis bubini põrinat just kuuvalgetel öödel. Kuu andis valgust pikka ja pimedasse põhjamaa öösse ja sellistel kordadel viibisin tihti oues.

Trumm on šamaanil hädavajalik abivahend. Ta kasutab trummi heade vaimude appikutsumiseks. Rännakute sooritamisel üla- või allmaailma saab trummi kasutada kilbina, kas või ründavate vaimude noolte vastu. Rännakuteks vajab šamaan abivahendeid, näiteks võtab ta rituaalide läbiviimiseks ja teadvuse seisundi muutmiseks sisse hallutsinogeenseid aineid. Tšuktši šamaanid kasutasid hallutsionogeenina punast kärbseseent (Amanita muscaria). Seentes olev vaim on šamaanile abimeheks ja nii siseneb ta vaimudeilma. Kurje vaime on vaja kontrolli all hoida, headelt on vaja abi paluda. Vaimudeilmast tagasi pöördudes on šamaan tavaliselt oma töö teinud ja haigustekitaja või vaenlase leidnud ning saanud teavet teda huvitavate küsimuste kohta, mida ta siis tagasi tulles rakendab.

V. Bogoraz-Tan kirjutab, et kohati viisid tšuktšid ohverdamist noorkuule läbi igal kuul. See ohver koosnes veresupist, lihast, rasvast ja põdrafiguuridest, mis olid tehtud purustatud puulehtedest. Põtru tapeti sel juhul harva, vahel ainult talvekuudel.

Ühel õhtul oli kuulda Vaegi küla taga asuvas olevast üksikust jarangast bubini põrinat. Olime parasjagu õues virmalisi vaatamas ja küsisime kohalikelt, mis seal toimub. Vastuseks kuulsime, et šamaan ravib kedagi. Palusime tüdrukuid meid seda vaatama viia. Tüdrukud nõustusid.

Kergitades jaranga sisenemisava katvat nahka, nägime lõkkevalguses põrandal lebavat inimest. Teisel pool lõket hüples bubinit mängiv šamaan üles-alla. Ta oli ekstaasis ja ei märganud meie tulekut. Aeg-ajalt sooritas ta õhus ligi meetri kõrgusi hüppeid, samal ajal põhjapõdravasika sääreluuga trummi tagudes. Lõkke ees lamas keegi liikumatult. Tagaseina ääres olid mingid inimesed istet võtnud.

Kui Niina küsis, kas me võime lõkke äärde istuda, katkestas šamaan oma tegevuse ja meid tabas hirmuäratav kriiskav tšuktšikeelne sõimulaine. See pidi olema midagi hirmsat, sest tüdrukud kangestusid ja põgenesid meid käistest kaasa kiskudes.

Mis neile öeldi, see jäi meile saladuseks, sest meie hilisematele palvetele viia meid šamaaniga vestlema vastati alati 
keeldumisega. Samuti ei rääkinud keegi, mida šamaan oli ütelnud.

Hiljem, tagasi Eestis olles lugesin Bogoraz-Tani, kes kirjutab: "Tšuktši šamaanid on erakordselt ettevaatlikud oma tegevuse näitamises muulastele. Eriti on nad kartlikud oma tegevuse algusperioodil. Kuid isegi väga suurte võimetega šamaanid keelduvad muulastele näitamast oma kunsti. Nad teevad seda ainult pärast korduvaid ja tungivaid palveid, kuid isegi siis nad ei näita kõiki oma võimeid ja võimu.

Nad kardavad mujalt tulnuid, keda nad ei tunne. Nad kardavad tulnukate bubineid ja nende kaitsevaime, mis võivad olla peidetud tulnukate kottides, samuti võõraid "hingi" ja "vaime", mis tiirlevad ja lendlevad tulnukate ümber. Vähimgi vahelesegamine tulnukate poolt või isegi kahtlus, et nad tahavad seda teha, lõpetab šamaani seansi" (Siimets 1999: 147).

Päevikut sirvides leidsin ma veel ühe kirjelduse 1971. aasta märtsikuust. Ravijaks ei olnud seekord mitte šamaan, kes oli naisterahvas, vaid mees põhjapõdrakarja juurest. Ta oli karja juurest puhkusele saanud ja Vaegi sõitnud.

Sel õhtul olime ühel kohalike neidude korraldatud peol. Muusika mängis, võeti mõned pitsid ja tantsiti. Toon ära katkendi päevikust.

Siis hakkasid kõrvalmajast kostma trummilöögid. Tundsime huvi, et mis seal toimub. Ljuba ütles, et neil elab seal üks meesterahvas, kes oskab inimesi ravida. Täna täiskuu väljas ja hea ravida.

"Kas ta on šamaan?"

"Ei ole, aga ta lihtsalt aeg-ajalt ravib abivajajaid. Meil siin iga karja juures inimene, kes ravib."

"Mis see täiskuu siia puutub."

"Pidi olema kergem ravida."

"Äkki saaks vaatama minna."

"Lähme."

Panime riided selga ja läksime kõrvalmaja ukse taha. Tüdrukud hakkasid ukse peale koputama. Mina läksin maja nurga taha ja vaatasin aknast sisse. Kardinaid ei olnud ees ja aknast paistis mingi bubiniga rahvuslikes riietes mees. Keegi lebas selili voodil. Tüdrukud kolkisid ukse peale. Mees lõpetas 


\section{Ülo Siimets}

trummi põristamise ja küsis midagi. Tüdrukud vastasid talle tšuktši keeles ja seletasid kiiresti midagi . Saime aru ainult sõnadest etteki (tšuktši keeles 'tere') ja yanki. Nägin läbi akna tšuktši mehe vihast nägu ja kuulsin tema sõimu. Sisse meid igatahes ei lastud ja tüdrukud ütlesid, et naaber on halvas tujus. Läksime tagasi oma peomajja.

Tundsin huvi ravimise vastu ja küsisin Ljubalt, et kas ta oskab ütelda maagilisi loitse, millega ravitakse inimesi. Ta ütles, et sellised loitsud saadakse tavaliselt päranduseks oma esivanematelt. Tema vanaema ja vanaisa said 1950. aastal võitluses venelastega surma ega jõudnud seetõttu anda neid loitse tema emale ja isale edasi. Põhjapõdrakarjade juures jäid paljud vanemad inimesed ellu, nemad kandsid vana tarkust edasi. Paljud karjused teavad mingeid loitsusõnu, aga nende juurde käivad maagilised tundmatud sõnad või vormelid. Ilma selle vormelita loitsud ei mõju. Nendel sõnadel ei ole tähendust. Neid teavad ainult vähesed, nn teadjamehed. Neid teadjamehi on iga põdrakarja juures ja see naaber ongi üks selline mees.

Hiljem, kui põhjapõdrakarjusena töötasin, käisin iga päev hommikust õhtuni ringi koos Ejgeliga, kes oli meie karja teadjamees-šamaan. Temalt kuulsin, et paljudes loitsudes meenutatakse päikest, kuud, Linnuteed, Koidutähte ja erinevaid tähtkujusid. Ejgeli rääkis tõemeeli, et loitsude abil on võimalik tappa vihavaenlasi. Sellepärast teavad selliseid loitse ainult šamaanid ja neid hoitakse kiivalt saladuses. Näiteks kui sa tapad täiskuu ajal põhjapõdra, lausud kuu poole pöördudes õiged sõnad, lõikad põhjapõdral pea maha, paned pea terava teiba otsa, lausud jälle õiged sõnad, paludes kuu abi, lisad õige vormeli ja lööd teiba koos peaga tundras maa sisse, jääb su needuse alla pandud vaenlane elu lõpuni halvatuks. Eigeli lisas, et mulle ma neid sõnu ei ütle, muidu hakkan äkki lollusi tegema. Valesti ja ebaõiglaselt neid loitse kasutades saavat ise karistada. Hädaohtu satub siis, kui vaenlase kaitsevaimud on loitsija omadest tugevamad. Kui vaenlane teab ka loitsusõnu, siis pöördub needus esimese loitsija enda vastu.

Sellised uskumused, et loitsude või nõidusega võib tappa, valitsevad kõikjal maailmas. Eesti Televisiooni "Pealtnägija" saates edastati alles hiljuti filmilooik Uus-Meremaalt, kus inimesi tapeti lihtsalt selle eest, et neid arvati olevat nõiad. Nõia enda tapmise nõiutu sugulaste poolt kiitsid heaks isegi oletatava nõia sugulased. 
Okeaanias elava elema rahva nn armastajad kehastavad papareti (kuud), kes müütilistel aegadel tõmbab naisi magnetina ligi. Nimetades end kuu salajase nimega Marai, loodavad mehed muutuda vastassugupoolele samavõrd vastupandamatuks (McKenzie \& Prime \& George \& Dunning 2002: 146).

Järgnevalt räägin ühest tšuktši põhjapõdrakarjuste ohverdamisriitusest, mis leidis aset täiskuu ajal.

Saabus august. Suve jooksul olid põhjapõtrade sarved kasvanud suureks, aga nad olid ikka veel naha ja karvadega kaetud.

Tundras olid juba nädal tagasi ilmunud samblast välja seened. Esimeste seente ilmumine ajas põdrakarja ärevile. Põhjapõdrad ajasid ninad õieli ja vahtisid vastutuult kaugusesse. Niipea, kui loomad ringist välja lasti, tormasid juhtpõdrad seente suunas. Teised tormasid neile kiiresti järele. Tundras toimus lahinghargnemine nagu sõjaväes. Ühe hetkega oli üle 4200 looma mööda tundrat laiali. Igaüks püüdis leida oma seent. Saanud ühe seene kätte, tormas ta, nina õieli, järgmise järele. Saanud sellegi kätte, haaras ta seene suhu ja tormas järgmise järele. Põhjapõdrad olid jooksnud nii kaugele, kui silm ulatus.

Olin koos tšuktši karjuse Ejgeliga karjas ja me ajasime mahajäänud põtru esimestele, juhtloomadele järele. See oli raske töö, sest loomad käitusid nagu hullud ega allunud käsklustele. Tänu karjalaika väledusele õnnestus meil siiski kari kokku saada. Kui põhjapõdrakari taas lahti lasti, kordus jälle kõik.

Mida aeg edasi, seda rohkem seeni tuli sambla seest välja. Kohati ilmusid nähtavale terved seeneringid, nii et maa peal olid nagu olümpiarõngad. Sellise seenehulga juures muutus kari jälle rahulikuks.

Enamik seentest olid puravikud. Oli ka muid, aga neid oli vähe. Küsisin Ejgelilt, miks tšuktšid puravikke ei korja, need on ju nii maitsvad. Ejgeli vaatas mulle imestunult otsa ja ütles: "Aeg-ajalt ajad sa niisugust juttu nagu mõni loll tanng. ${ }^{1}$ Kas sa ei näe, mida seened põhjapõtradega teevad? Loomad lähevad ju lausa hulluks, kui nad seenelõhnagi tunnevad. Kas sa tahad muutuda sama lolliks kui nemad on? Lase siis käpuli maha ja söö neid, nii et kõht paistes. Vaata, mis siis juhtub.”

"Meil süüakse kodus küll puravikke ja pilvikuid. Meil on puravikest isegi laul, et võiga praetud puravikud valge viinaga on head. Eriti maitsevad mulle kukeseened," vastasin mina. 


\section{Ülo Siimets}

"Näed, ise sa ka räägid, et valge viinaga on head. Kust sa siin valget viina võtad? Kodus sa sööd seeni viinaga ja siis sa ei saa arugi, et oled seentest segi läinud. Pärast arvad, et näe, viina sai liiga palju joodud, võttis peast segi.”

"Me sööme puravikke ja muid seeni ka ilma viinata ja midagi ei juhtu. Meil on palju seeneroogi: seened soolatult, marineeritult, praetult..."

Tšuktši võttis minu viimane jutt lausa mõtlikuks ja ta vastas: "Meie korjame ja austame ainult punast kärbseseent. Kärbseseened on väga tugevad. Nad võivad kasvades purustada isegi puujuuri. Muidugi teevad seda ka mõned muud seened, aga kärbseseene tegelik jõud peitub selles, et ta on võimeline viima sind teise maailma. See sõltub muidugi sellest, kuidas sa oskad neid meelitada. Peamine on see, et sa ei sööks kunagi paaris arvu seeni."

Ejgeli seletas:

"Tarkus on selles, et kui sa sööd kaks seent, siis kohtuvad kolm vaimu, sinu vaim ja kaks kärbseseene oma. Hea, kui üks nendest on sinu poolt, siis ei juhtu midagi halba. Kui nad aga kahekesi pööravad sinu vastu, võtavad nad sinu vaimu kaasa. Siis nad sinu vaimu võib-olla kehasse enam tagasi ei lasegi ja oledki surnud. Kui süüa algul kolm punast kärbseseent, siis on üks seenevaimudest ikka sinu poolt ja jõud on tasakaalus, see tähendab, et kõik sõltub sinu enda tahtest. Inimene, kes sööb kärbseseent, võib näha isegi kärbseseene vaimu. See vaim võib võtta sind käekõrvale ja viia surnute riiki, kus sa võid kohata oma esivanemaid. Šamaanid kasutavad punast kärbseseent, et leida ketljade poolt varastatud hingi. Vanad inimesed rääkisid kärbseseenerahvast. Need on ühe käe ja ühe jalaga inimesed. Nad võivad olla sulle suureks abiks."

Rohkem me seekord sel teemal ei vesteldud. Õhtul, kui karja kokku ajasin, nägin, kuidas üks põhjapõder nühkis oma nahaga kaetud sarvi vastu pajupõõsast. Nühkides tuli nahk sarvede küljest lahti. Paljastusid punased verised sarved, mille küljes tolknesid üksikud naharibad.

Õhtul lõkke ääres istudes ja vaadates, kuidas lihakatel tulel keeb, ütlesin ma Vatapile, et täna nühkis üks suur põdrapull sarved nahast puhtaks. Ejgeli oli kuhugi kadunud ja Vatapi kord oli meestele õhtuks liha keeta. Vatap vaatas mulle imeliku näoga otsa ja hõikas tšuktši keeles meestele, et tuldagu tema juurde. Pärast Ejgeli lõkke juurde tulekut hakkasid karjused tasakesi midagi omavahel arutama. Pärast tuli Ejgeli minu juurde ja ütles: 
"Teeme karjaga väikese tiiru. Sina puhka siin. Jätame sind telgiga siia. Tagasi tuleme kolme-nelja päeva pärast. Sinu vintpüss ja padrunid jäävad ka siia, võid jahil käia. Tolle sopka taga on väga tihti lumelambaid. Võib-olla saad mõne kätte, siis on tore süüa. Praegu on nad juba väga rasvased."

Taipasin juba asja mõtet ja vastasin Ejgelile: "Mina rändan koos teiega, magan koos teiega, söön sama sööki mida teie, joon sama vett nagu teie, hingan sama õhku nagu teie. Riietus on mul ka samasugune kui teil. Vahe on ainult selles, et teil on nahkriided ja mul presendist, aga see ei tähenda midagi. Ühesõnaga, ma elan koos teiega ja seega olen ma samasugune karjus nagu teie, seega tšuktš nagu teiegi. Ma arvan, et ketlja ei pahanda, kui ma teiega kaasa tulen."

Ejgeli ei vastanud midagi. Ta läks teiste karjuste juurde. Nad arutasid seda küsimust omavahel. Natukese aja pärast tuli Ejgeli tagasi ja ütles: "Olgu, tule siis kaasa, kui sa nii väga tahad."

Loomulikult tahtsin ma kaasa minna.

Liikusime kaks päeva ühes kindlas suunas.

\section{Ohver ketljale}

9. augustil õhtul hakkas täiskuu sopkade vahelt aeglaselt üles ronima. Karjused püüdsid tšaadiga ühe hästi tugeva ja ilusa põhjapõdrapulli. See loom oli musta värvi ning alles hiljaaegu sarved nahast vabastanud. Loom tiriti tšaadiga kõrvalasetseva väikese sopka otsa. Põder kargles ja hüples nööri otsas. Ta oli üsna tugev, nii et teda oli vaja lausa mitme mehega kinni hoida. Kui lõpuks sopka otsa jõuti, jäädi ootele. Ejgeli oli ennast keeranud näoga sopka all oleva oru poole ja laulis midagi tšuktši keeles. Laulu salmide vaheajal kõlas jälle nii tuttav monotoone: "Iiiii, aaaaa, ooooo, uuuuu..."

Siis võttis ta aeglaselt oma rituaalioda tupest. Mehed tõmbasid tšaadi pingule. Vahepeal vaikselt liikumatuks jäänud põdrapull hakkas jälle hüplema. Mehed hoidsid põhjapõtra pinge all. Pull väsis hüplemisest ja jäi seisma. Siiski osutas ta vastupanu, toetades kõik neli sõrga tugevasti vastu maad. Nii oli tal keha tahapoole kaldu nagu vastupunnival loomal ikka. Ta silmad läksid punni ja ta kõõritas nendega kõrvalseisvate karjuste tegevust.

Ejgeli tuli lähemale. Põder, aimates halba, hakkas uuesti nööri otsas hüplema, aga seda ei olnud kauaks. Varsti seisis ta jälle tar- 


\section{Ülo Siimets}

dunult, jalad ette poole suunatud, et ťšadi pingele vastu panna. Seda karjused ootasidki. Sellises asendis oli kõige lihtsam torgata kas noa või odaga vasaku külje pealt otse südamesse. Ejgeli tegigi seda, lüües rituaaliodaga tugeva löögi esijala tagant põhjapõdra rindu ja tõmmates oda kähku jälle rinnust välja. Haavast purskus kohe veri. Põhjapõder hakkas metsikult hüppama ja karglema. Karjused pingutasid tšaadi. Põder vajus algul põlvili, siis külili.

"Esialgu on kõik hästi läinud," lausus Ejgeli. Ta mõtles selle all pulli langemist paremale küljele. See tähendas, et ketljale oli väljavalitud loom meelepärane. Vastupidisel juhul oleks loom kukkunud vasakule küljele, nii et veri oleks rindkerest välja voolanud. Siis oleks tulnud uus loom välja valida ja see ohverdada. See oleks kordunud seni, kui oleks leitud ketljale sobiv ohver.

Põdrapulli pea asetati oru vastas oleva sopka suunas. Loom nüliti sealsamas lõkke ääres. Sisikond võeti välja. Põdrakoljust lõigati silmad terava noaga välja. Kolju ise raiuti pikkupidi pooleks, jättes sarvede külge suurema koljuluu riba kui tavaliselt.

Kogu see tegevus toimus vaikselt, ilma jutuvadata. Oli kuulda ainult meeste nohinat. See on üks tšuktšide tavadest, et loomade nülgimise ajal on keelatud naerda, vilistada ja üldse on parem, kui sel ajal vaikitakse.

Ejgeli võttis põhjapõdra rindkerest kamaluga verd. Ta määris sellega sarved ja asetas need vastu maad, teravad tipud allapoole, nii et koljust moodustus midagi kausitaolist. Ka tekkinud kaussi tõstis ta kamaluga verd. Vere sisse asetas ta ühe põhjapõdra silma. Silma kõrvale pani ta tükikese maksa, tükikese neeru, tükikese südant, tükikese kopsu ja tükikese reieliha. Seejärel võttis ta kogu selle andami ja läks alla orgu.

Täiskuu oli tõusnud kõrgele ja kuuvalgus valgustas selgesti ümbruskonda, mis enne oli mattunud pimedusse. Ma vaatasin huviga meeste tegevust ja suunasin siis pilgu Ejgelile järele. Korraga märkasin, et kuuvalgus, mis valgustas nüüd vastasolevat sopkakülge, tekitas imeliku aistingu. Mingi nurga all paistes moodustasid täiskuu poolt tekitatud põõsaste ja kivide varjud vastasolevast sopkast inimpea kujutise. Sellel mehepeal olid silmad, nina, suu, vuntsid ja habe ning ta vaatas ülevalt alla orgu. Ejgeli oli üsna kaugel, aga siiski oli näha, kuigas ta mäejalamil kummardus ja annid maha pani. Lõkke juurde oli kuulda tema laulu: "Iiiii, aaaaa, uuuuu, ooooo..."

Mehed istusid rätsepaistes lõkke äärse ja kõigutasid ennast ümina taktis ette-taha. Kui ma sellest aastaid hiljem Vigala Sassile rää- 
Ülo Siimets

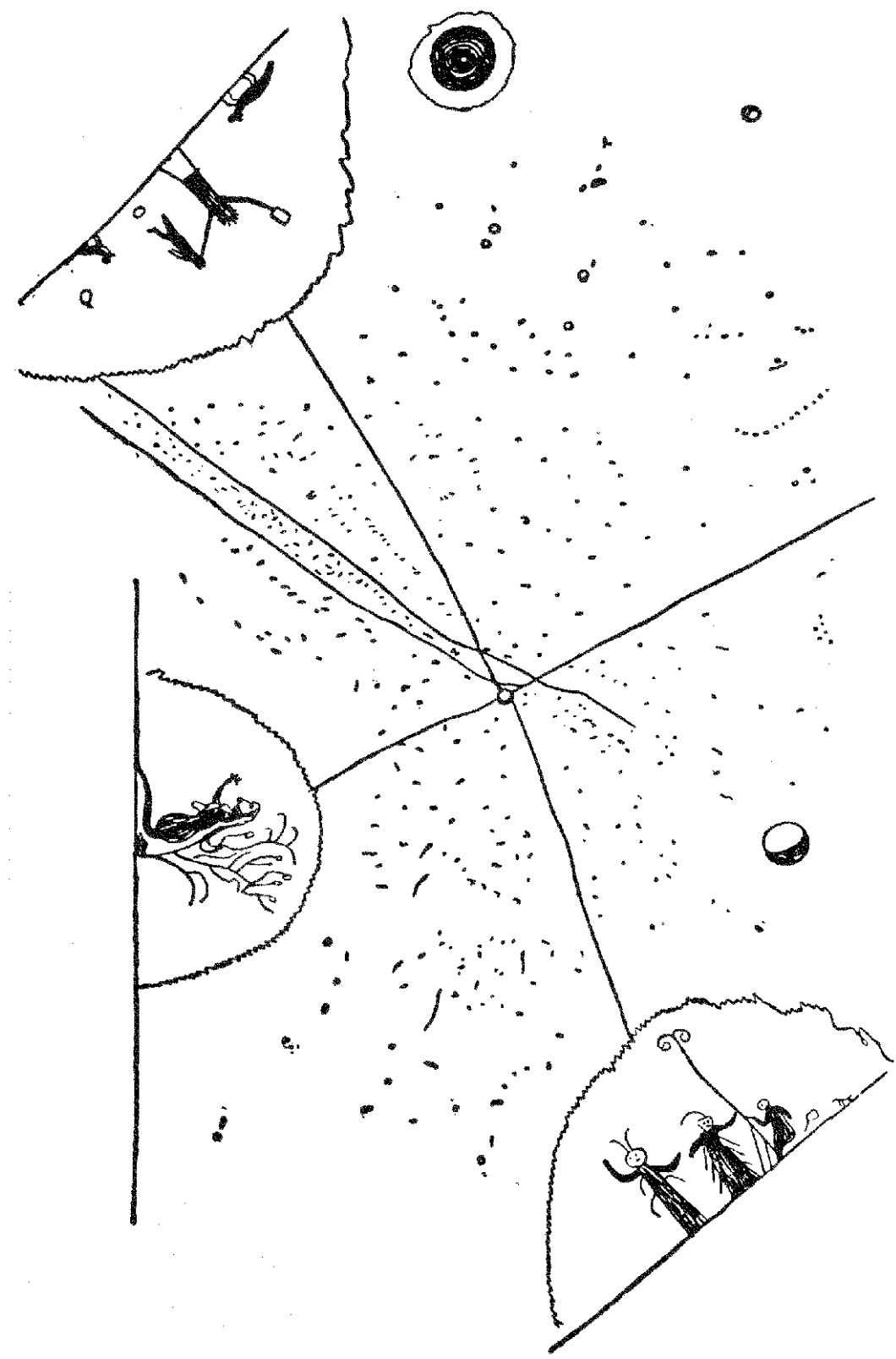

Joonis 1. Tšuktšide taevakujutelm Vladimir Bogoraz-Tani järgi. 


\section{Ülo Siimets}

kisin, ütles ta, et selline laulmine (täishäälikute kordamine) mõjutab solar plexust (päikesepõimikut). Nii lauldes, sisemiselt ümisedes ja ennast kõigutades on võimalik saavutada kaifi ja tunda vabanemist. Üldse saab inimesi mõjutada nii heli kui ka rütmi kaudu. Rütmi sisse saab panna sõnumisi ja loitsusid, et mõju oleks suurem. Vigala Sass väidab end olevat teinud mõõtmisi, et kui riituse ajal trummi põristada, muudab vibratsioon ioonid positiivsemaks, st neutronitele lisandub laeng ja nad muutuvad katioonideks. Eriti huvitav olevat seda jälgida kultuseplatsidel, kus loodus hakkavat lausa vohama. Sama võivat teha ka lauluga.

Seda kasutatakse ära kõikide regioonide ja ühisürituste juures: kirikutes, palvelates, laulupidudel, ööklubides ja diskoteegis. Aga olemuselt on see puhas hüpnoos ja autosugestioon.

Kui Ejgeli tagasi tuli, pandi liha katlasse keema. Ejgeli lõikas põhjapõdrapea küljest järelejäänud silma ja poolitas selle siis noaga peo peal. Silmavedelik jooksis silmast välja peo peale. Ta jõi algul silmavedeliku ära, pani siis põdrasilma suhu ja neelas alla. Tema oli sellel ohverdusüritusel tähtis tegelane - riituse läbiviija. Silmad antakse ainult kõige tähtsamatele külalistele. Sellel üritusel oli neid kaks: ketlja (vaim) ja šamaan.

Natukese aja pärast võeti katlast poolenisti verine liha ja hakati sööma. Kui see otsa sai, pandi uus laar liha keema. Pärast tõsteti põdrakerest kamaluga verd ja pandi lihaleeme sisse. Veem otsis oma seljakotist juurikaid, mida lisati keedetud verele. Kui veri enam luulusika külge ei hakanud, võeti katel tulelt ja pandi ringi keskele. Iga mees võttis vöölt oma lühikese varrega luulusika. Järgemööda hakati sellega võtma veresuppi ja kuumale supile peale puhudes seda sööma. Üle hulga aja söödi nõrkemiseni. Veem ja Vatap läksid karja juurde ja vahetasid sealolevad mehed välja, et need saaksid ka pidusöögist osa võtta. Kell oli umbes kolm öösel, kui lõpuks telki magama mindi.

Hommikul, kui päike tõusis, oli näha, et teisel pool orgu oleva sopka jalamil oli väga palju sarvi. Kohati olid need hunnikutesse tõstetud, moodustades mitu ümarat sarvekuhilat. Ohvriand oli tänuga vastu võetud, sest sopkajalamil asetsevad sarved olid külili ja koljukaussi pandud annid kadunud.

Sarvekuhilate järgi võis aimata, et seda ohvripaika olid tšuktši karjused kasutanud juba aastakümneid. Selliseid sarvekuhilaid kutsuvad nad tönmajks. Neid võib leida matusepaikadest ja ka teistest ohverdamiskohtadest. 
Kui tavaliselt söödi põhjapõder täielikult ära, siis seekord lohistati järelejäänud lihakere tapmiskohalt alla väikese sopka jalamile ja jäeti maha. Seal ootasid ees eelmiste ohvriloomade luud. Konte oli näha paljude põõsaste all. Vaikides lahkuti sellest nukravõitu paigast.

\section{Maa ja eesti Tähemõrsja}

Maa (Nutenut) elab tšuktšidel legendi järgi suures raudses majas. Tal olid ühes loos külas Päike, Kuu, Taevas, Meri, Koit, Udu ja Universum. Kõik nad tahtsid abielluda Maa kaunitarist tütrega. See lugu meenutab mingil määral eestlaste müüti Tähemõrsjast, kuid selle lõpp on eesti loost erinev. Tähemõrsjas valib neiu endale peiuks tähe. Tšuktšid ei lase neiul peiut valida, vaid tegelased-peiud võistlevad ja võitja saab tüdruku naiseks. Võitjaks ei tule aga keegi ülalnimetatud kosilastest, vaid hoopis tšuktši šamaan Jettögöt, kes tõstab oma saua ja puudutab sellega rivaale. Selle tagajärjel süttib igaühe puudutatud külg ja nad põgenevad kabuhirmus. Ja Jettögöt saab tüdruku endale naiseks.

Muide, tšuktšidel ei ole polügaamia keelatud ja see on tänapäevani mitteametlikult levinud. Nagu eespool olevast tekstist näha, oli päiksel juba naine nimega Kavra-nya.

Tähed ja tähtkujud kuuluvad eespool nimetatud tähtsate olendite juurde (vaъrgbt).

\section{Põhjanael}

Suurimat tähelepanu pööratakse Põhjanaelale (tšuktši keeles Ilukejer (Liikumatu täht) või Olqep-ejer (Nael-täht) või Unp-ejer (Sissetorgatud Vai-täht, Post-täht). V. Bogoraz-Tan väidab, et tähe viimasena kirjutatud nimekuju on levinud kogu Euraasias. Põhjanael on taevas kui maasse torgatud vai, post, mille ümber käivad tähed nagu vaia külge seotud hobused või põhjapõdrad. Põhjanaela koda asub seniidi kohal, mille ülemise suitsuavause kaudu on võimalik liikuda ühest maailmast teise. Selle avause tõttu on Põhjanael nähtav kõikides maailmades, nii ülemises kui ka alumises, samas kui teised tähed ja tähtkujud erinevad meie maa- 


\section{Ülo Siimets}

ilmas nähtavatest. Samas arvatakse, et Põhjanaela koda asub teistest kodadest kõrgemal. Tema koda on tehtud jääsarnasest ainest ja selle tippu on kinnitatud valgusallikas nagu majakas (Bogoraz-Tan 1939: 23).

Andres Kuperjanov toob oma raamatus ära eri rahvaste Põhjanaela nimetused: Kuldne sammas (mongolitel, burjaatidel, kalmõkkidel ja Altai tatarlastel), Raudne sammas (kirgiisidel, baškiiridel ja Siberi tatarlastel), Üksik post (teleuutidel) ja Kuldne post (tunguusidel) (Kuperjanov 2003: 143). Kõik need rahvad on kujutanud Põhjanaela liikumata samba, posti või taevasse löödud vaiana. Nii ka tšuktšid. Ka tšuktšikeelne nimetus Nael-täht sarnaneb otseselt eestikeelse nimega Põhjanael.

\section{Arktuurus ja Veega}

Tähtsuselt järgmised tähed peale Põhjanaela on tšuktšidel nn pead (tšuktši keeles Leutti). Pead koosnevad kahest tähest. Esimene pea on Karjase tähtkujus asuv Arktuurus (tšuktši nimi Janotlaut, eesti Karuvalvur) ja Tagumine pea Lüüra tähtkujus asuv Veega (tšuktši Jaatlaut, eesti Vabamees, Voorimees). Need tähed on tšuktšidel omavahel vennad või tädipojad.

Öises tundras liikudes kasutavad tšuktšid peade omavahelist asendit ja Põhjanaela asendit õige orientiiri leidmiseks. Arktuurust kutsutakse sageli ka ülemuseks ehk tähtede juhiks (Bogoraz-Tan 1939: 24).

Mõlemaid tähti kasutavad tšuktšid ka abimeestena ravimisel. Haiguste korral tuleb tuua ohver Arktuurusele ehk Esimesele peale. Maovalu puhul tuleb ohverdada ja loitsuga pöörduda Veega ehk Tagumise pea poole.

\section{Sauatähed, Orion jt taevakehad}

Sauatähtedeks on olnud kolm reas olevat tähte Kotka (Vanad Sauatähed) ja Orioni (Uued Sauatähed, Sandisauad) tähtkujus (Kuperjanov 2003: 177).

Kotka tähtkuju $\alpha$ (Altair) ja $\gamma$ (Tarared) on tšuktšidele erilise tähendusega. Neid kutsutakse nimega Pettig๖n. Tšuktšidele toob see 
Kotka tähtkuju uue aasta, sest ta ilmub horisondile esimest korda talvise pööripäeva ajal. Nii põhjapõdrakasvatajad kui ka rannikutšuktšid viisid vähemasti varemalt sel puhul läbi ohverdamisi. Selleks ohvriks sobisid eriti rasvased põhjapõdrapullid. Muude pühade ajal ohverdatakse vahel verd ja põdrad asendatakse taimedest või lumest tehtud sümboolsete kujudega (Bogoraz-Tan 1939: 75).

V. Bogoraz-Tan oli kuulnud nii Anadõris kui ka Kolõmal, et Pettigøn olevat olnud suguharu pealik, kes tõsteti taevasse. Kahjuks ei õnnestunud tal sellel teemal rohkem materjali koguda (BogorazTan 1939: 24)

Teisi tähtkujusid ei pea tšuktšid erilisteks olenditeks (vaъrgъt). V. Bogoraz-Tan on loetlenud neist tähtsamad.

Orion on tšuktšidel Rultennin (Küürakas). See on küürselgne vibulaskja. Orioni täht $\lambda$ on tema pea, $\alpha$ ja $\gamma$ - õlad, $\kappa$ ja $\beta$-jalad. Orioni vöö on Küüraka küürus selg. Kaks suurt tähte vööst otse alla on Küüraka suguelund.

Lõvi tähekuju nimeks on tšuktšidel Vetcanaut (Seisev Naine). Seda nimetust kasutatakse tavaliselt rahvatantsus osalevate naiste kohta. Seisvat naist peetakse rahvapärimuses Küüraka (Orioni) naiseks, kes magab palja maa peal. Temakene armukadetses Orioni, kellel tekkis kirg Plejaadide vastu, ja ta lõi Küürakat juurdelõikuslauaga. Löök oli nii tugev, et vigastas mehe selga. Seetõttu ongi mehel küür. Pärast löömingut ajas Orion naise kodust ära ja see on sunnitud siiamaani ööbima kesktaevas.

Lõvi tähekuju koosneb seitsmest tähest. Täht $\varepsilon$ on naise pea, $\eta$ tema turi, Reegulus naise põlv, väike $\varepsilon$ ja $\eta$ vahel asuv täht aga padi, mille peale toetub lamava naise pea. Teised tähed moodustavad keha piirjooned.

Plejaade (Sõela) kutsuvad tšuktšid nimega Nausqatiomkın (Grupp Naisi). Need on kuus vallalist neidu, kes ootavad mehi. Küürakas püüdis pärast vigaseks jäämist ja naise kodunt äraajamist ükskõik kellega neist abielluda, aga kõik neiud põlgasid ta ära, sest mehel oli liiga suur suguorgan (penis). Pealetükkiv peigmees võttis vibu ja asus tulistama neidusid, kes põgenesid hirmunult tema laskeulatusest kaugemale. Sõnni tähtkuju peatäht Aldebaran ongi Orioni lastud vaskse otsaga nool. Nii teda tšuktši keeles ka kutsutakse Celgb-maqъm (Vaskne Nool). Nool aga ei jõudnud lennata põgenevate naisteni ja kukkus samblasse. Küüraka vibu on kaarjas, vibu meenutav täherühm Orioni ja Aldebarani vahel. Kolõma tšuktšid jutustavad oma müüdi variandis, et rahulikult kaugemal seisvad Grupp Nai- 


\section{Ülo Siimets}

si kaitsevad ennast võrkudega. Võrgu moodustavad mitmed väiksed tähed, millesse on kinni jäänud Vaskne Nool (Bogoraz-Tan 1939: 25).

Kreeka mütoloogias oli Orion Boiootiast pärit metsik ja vägev kütt, kes jälitas Plejaade. Ka paljudel Siberi rahvastel seostub Orioni tähtkuju jahiga. Eestis on taevas hoopis taevaliste majapidamisriistad: Koot ja Reha on Lõuna-Eesti tähtkuju, kuid ka Lahemaal ja Saaremaal seostatakse Orioni rehepeksuga, ent seal on ta nimeks Vart, Vardatähed (Kuperjanov 2003: 165).

Sõel on oma kompaktsuse ja eripära tõttu tuntud kõikjal, kus ta paistab. Peamiselt on nähtud Sõelas inimesi (enamasti tüdrukuid), seemneid, kanapoegi, linnupesa. Sõela üheksal tähel on klassikalises astronoomias igaühel oma nimi: need on Atlas ja merenümf Pleione ning nende seitse tütart Alcyone, Maia, Asterope, Taygeta, Celaeno, Electra ja Merope, kelle Zeus tõstis taevasse, kui nad põgenesid Orioni eest, kes Meropet endale naiseks tahtis (Kuperjanov 2003: 183). Huvitav on märkida, et see klassikaline variant läheneb tšuktšide kujutusele Orionist ja Plejaadidest.

Veomehe (Auriga) täht $\alpha$ ehk Kapella (Jõulutäht) on tšuktšidel põhjapõdrapull, kes on rakendatud inimese $(\varepsilon)$ narta ette, mida veavad kaks põtra, ette. Kõiki nelja tähte kutsutakse tšuktšidel CъmyaNletelın (Juhitud Pullid). Selle tähtkuju $\beta$ on nahast kaelarihm, mille on kaotanud teised põtradega sõitjad, kes on pöördunud tagasi seda otsima. Nende saani juurde kuulub ka tagavarapõdrana narta külge kinnitatud põdrapull $\delta$, kes jookseb saani kõrval. Teisest küljest läheneb nahast kaelarihmale rebane (Bogoraz-Tan 1939: 25).

Jakob Hurda kogutud materjalides sisaldub eestlaste uskumus, et Kapella olevat olnud päris Jõulutäht, see, mis ennemuistsel ajal Kristuse sünnist märku andis ja hommikumaa tarku Petlemma juhatas (Kuperjanov 2003: 163).

Suur Vanker on tuntud kõikjal maailmas, kus teda näha on. Koos Orioniga moodustavad nad niivõrd kindlapiirilised tähtkujud, et neid on võimatu kuidagi teisiti ette kujutada. Klassikalises astronoomias on Suur Vanker Suur Karu, paljudes ingliskeelsetes maades hoopis Big Dipper (Suur Kulp). Tatarlastel on Suur Vanker maailmalôpu enne: Suur Vanker on seitse koera, kui need panevad jooksu, on maailma lõpp käes.

Germaani usund tunneb Suurt Vankrit kui Odini, hiljem ka Karli Vankrit, Hiinas on tähtkuju nimeks Imperaatori Kaarik (Kuperjanov 2003: 180-182). 
Ometi ei ole tšuktšidel ühtset Suur Vanker tähtkuju. Kuus tähte on Wъjotkъnaulъt (Linguheitjad). Seitsmes täht, mis, nagu teada, on kaksiktäht, on rebane, kes järab mahajäetud põhjapõdrasarvi.

Kaksikute tähtkuju Kastor ja Polluks on kaks põtra, kes põgenevad kahe jahimehe eest. Kumbki kütt sõidab põhjapõdrarakendiga. Ühel neist meestest on narta külge seotud koer. Tšuktšidel kutsutakse tähtkuju Gopka-velerkßlelъt (Jahimehed Põtradega). Jahimehed on tähed $\gamma$ ning $\chi, \lambda$ ja $\eta$ kõrvaltähtkujust.

Põhjakroon (Corona Borealis) on tšuktšidel Valge Karu Käpp. Delfiini tähtkuju on Hüljes, kusjuures selle täht $\varepsilon$ on looma pea ja neli tähte lestad. Linnutee on tšuktšidel Cigej-veem (Liivajõoi), mis voolab läände. Jões on palju saari (Bogoraz-Tan 1939: 25).

Muinas-Egiptuse müüdis ilmus jumal-looja Atum ürgookeanist Nunist. Oma seemnest, seega ühtsusest, lõi ta duaalsuse, mida esindasid kaksikud valguse- ja õhujumal Šu ning päikeseketast kehastav emalõvi Hathor-Tefnut. See paar sigitas naissoost taeva Nuti ja meessoost maa Gebi. Nuti kujutati varvaste ja sõrmedega maad puudutava naisena, keha taevakaart moodustamas. Tähed tema kehal moodustavad Linnutee. Geb ja Nut omakorda sigitasid nn Osirise tsükli jumalad. Vanim poeg Osiris päris Gebilt kuningavõimu. Osirise kaaslaseks oli tema õde Isis, kes võis olla algselt kuningavõimu sümbol. Samuti kehastas Isis täht Siiriust. Seth tappis Gebi kuningavõimu pärast tekkinud tülis Osirise, tükeldas surnukeha ja pillutas tükid mööda Egiptust laiali. Selle episoodi põhjal tekkis palju Osirise kultuse keskusi ja igaühel oli väidetavalt reliikviaks mõne jumala kehaosa tükike. Pärast Osirise mõrvamist rändasid tema õed Isis ja Nephthus kogu maal tema kehaosi kogudes ja kokku pannes ning mõneks ajaks õnnestus neil Osiris elustada. Osirise samastamine Orioni tähtkujuga, mis on aastas umbes 70 päeva nähtamatu, peegeldab egiptlaste 70-päevast palsameerimisrituaali. Isis hõljus loorkullina Osirise erekteerunud peenise kohal ja eostas end. Talle sündis poeg Horos. Isis oli sunnitud peitma Horose Sethi eest kõrkjatesse. Teda aitasid Uto ehk Uadzit (eesti keeles 'värske, roheline') ja Al Kabist pärit raisakotkas Nehbet, kellest kumbki esindas üht kahest tähtsamast kuningakroonist (McKenzie \& Prime \& George \& Dunning 2002: 35-37).

Kassiopeia tähtkuju viis suurt tähte on tšuktšidel viis põhjapõtra, kes seisavad keset jõge. 


\section{Ülo Siimets}

Komeete nimetavad tšuktšid suitsevateks tähtedeks. Sõna "suitsev" viitab sellele, et tšuktšide arvates elavad komeetidel mingid olendid, kes keedavad kogu aeg süüa.

Planeetidele on tšuktšid andnud nime "kõveralt käivad tähed", mis tuleneb nende näiliselt ebaõigest liikumisest taevas.

Koidutäht ehk Veenus kannab tšuktšidel nime Gъto-tlap. Sõna esimene osa tähendab tšuktši keeles 'suur, tugev'. Sõna teist osa ei oska tšuktšid seletada, aga arvatavasti on ta seostatav korjaki sõnaga lelapъcan, mis tähendab tähte ja on omakorda tuletatud tegusõnast lelapekъn ('vaatama'). Sel juhul oleks Veenuse tähenduseks Suur täht või Suur Silm.

Hommikutähena nähtavat Veenust nimetavad tšuktšid ka Kergayatlıyъn (Hele täht). Tšuktšid räägivad, et Veenus on mъkevirınlın (mitmerüüline), mis tähendab, et ta helendub erinevatel aegadel erinevalt (Bogoraz-Tan 1939: 29).

Koidutähega on seotud sumerite aastaaegade müüt. Akadi kuujumalannal Sinil (sumeri Nannal) oli tütar Ištar (sumeri Inanna). Teda seostatakse planeet Veenusega. Ta oli armastuse- ja seksijumalanna, tuntud oma rahuldamatu ja püsimatu loomu poolest. Ištari paljudest armastatutest oli kõige tähtsam Dumuzi (hiljem Tammuz), viljakus- ja taimekasvujumal. Jumalanna Ištar laskus allilma külla oma õele. Ta läks läbi seitsmest väravast, millest igaüks rebis temalt ühe rüü. Oma õe jumalanna Ereškigali juurde jõudis täiesti paljana. Ta jäi haigeks ja maa lakkas vilja kandmast. Vee, tarkuse ja nõiduse jumal Ea üritas Sini päästa, kuid tulemusteta. Siis halastas Ereškigal õele ja lasi Ištaril pöörduda tagasi maale. Seal leidis Ištar kõik oma teenrid leinamas. Ainult tema armastatu Dumuzi veetis lõbusalt aega. Karistuseks saadab Ištar Dumuzi igal aastal mõneks ajaks allilma (McKenzie \& Prime \& George \& Dunning 2002: 25).

Muinas-Egiptuses oli Horos jumalate kuningas ja teda samastati elava vaaraoga. Horose pistrikupea ja kaksikkroon näitavad teda ühelt poolt kui taevajumalat, Ra sugulast ja koidutäht Veenuse kehastust, teiselt poolt viitavad kuninglikule funktsioonile (McKenzie \& Prime \& George \& Dunning 2002: 35).

Tšuktšid ohverdavad Koidutähele mitmetel juhtudel. Pärast sügisesi noore põdra püha ohverdusriitusi on järgmine tähtis päev talvise jaranga ülespanek. Mina ise sellisest ohverdusest osa pole võtnud, sest sõitsin oktoobris tagasi Eestisse. Nagu kirjutab V. Bogoraz-Tan, ohverdatakse sel puhul kaks põhjapõtra Koidutähele ja 
üks maale. Ma olen varem kirjutanud tšuktšide ohvriannist Koidutähele, et võita kallima südant (Siimets 2003). Toon sellest loost katkendi:

Kui tšuktši karjus armub tšuktši neiusse, kes ei tee temast välja ega taha temaga abielluda, peab ta ennast peitma jaranga lähedusse või jaranga taha. Ühesõnaga, tüdruk ei tohi teda näha. Kui tüdruk läheb pissile, läheb karjus pärast tüdruku äraminekut lumele jäänud uriinilaigu juurde. Selle loigu juures peab ta lausuma järgmised sõnad:

"Mitte kusi ei kukkunud siia maha. Siia kukkusid maha sinu süda, maks ja neerud.”

Siis peab karjus ootama, kui tõuseb Koidutäht. Ta peab tooma ohvri Koidutähele. Aitab väikesest ohvrist, näiteks ohverdab ta kutsika. Rikas mees võib muidugi ohverdada ka põdravasika või põdra. Kui ohver toodud, palub karjus, et Koidutäht annaks talle rautatud saapad, millel on lausa teravad naelad talla all. Pärast seda läheb mees tagasi kuseloigu juurde ja hakkab selle koha peal jalgadega trampima. Sealjuures kordab ta pidevalt järgmisi sõnu (Siimets 2003: 231).

Sellist rituaali tuleb läbi viia seitse korda ja tüdruk on sinusse jäädavalt armunud.

Koidutähte saab kasutada ka oma armsama tagasitoomiseks teisest ilmast. Selleks tuleb surnu panna magamispologis (jaranga sees olev magamistelk) pikali põhjapõdranahkadest asemele ja minna jarangast välja Koidutähe suunas tundrasse. Siis tuleb ohverdada kutsikas Kõrgemale Olendile ja Koidutähele ning viia läbi rida protseduure, nagu surnu kõrva puhumine ja koera kombel haukumine. Viimane peletab minema surnu hinge kaasahaaranud ketlja ja hing pöördub tagasi oma kehasse.

Haige organi tervendamiseks tuleb varahommikul ohverdada Koidutähele.

Tšuktši jahimeestel on spetsiaalne püha, et õnnestuks metsikutele põhjapõtrade jaht. Selle püha hommikul ohverdatakse üks põhjapõder metsiku põhjapõdrapulli auks ja teine Koidutähele. Vahel tuuakse ka kolmas ohver Nadiirile. Tapetud looma soolikate ja verivorstiga kaunistatakse varem lastud metsiku põhjapõdra sarved. Valmistatakse rikkalik veresupp ja keedetakse liha. Viiakse ohvreid kõikidele koduvaimudele ja kaitsjatele. Pärast tapetakse noor põder ja tema verega määritakse põdrasarvi. Pühade ajaks tuuakse 


\section{Ülo Siimets}

ohverdatud põtrade pead jarangasse ja riputatakse lõkke kohale jaranga toepuu külge. Hiljem viiakse need sugulaste haudadele (Bogoraz-Tan 1939: 81).

Kui sinu jaranga juurde tuleb metsik põhjapõder ja sa tahad teda kodustada, pead oma loitsuga pöörduma Seniidi vaimu või seal elava kõrgema olendi poole. Sedasama tuleb teha ka siis, kui soovid lahti saada halvast ilmast.

\section{Kokkuvõte}

Terve elu peavad inimesed tegema valikuid. Inimeste valikutest sõltub, kuidas nad elavad. Nii on see ka tšuktšide juures. Tihti tuuakse uued usud ja uskumused sisse koos vallutajatega, nagu näiteks ristiusk Eestisse. Sellega kaasnevad uued nägemused, uued legendid ja müüdid, mis hõlmavad ka tähistaevast. Tšuktšid on vist ainukene rahvas endise Tsaari-Venemaa ja Nõukogude Liidu territooriumil, kes säilitas põhijoontes oma animalistliku usu. Ajaloost on teada, et. Tšuktšimaa oli Tsaari-Venemaa ainukene territoorium, millele oli antud tegelik autonoomia ja mis oli jäänud venelaste poolt lõplikult vallutamata.

Vastavalt Venemaa seaduste kogu ühele paragrahvile nimetati Tšuktšimaad Русская не вполне покоренная территория (Venemaa mittetäielikult alistatud territoorium) ja seal kehtisid kohalikud seadused.

Tšuktšimaa nime kandis maaosa, mis asus Tšauna ja Anadõri jõest lääne pool. Sealsed elanikud, nagu kõik lihtsad tšuktšidki, omasid teatud privileege otsustada oma asju, nende hulgas ka tapmisi ja sellega seotud veretasu, vastavalt oma vanadele tavadele. Seda juhul, kui selline kriminaalne asi toimus nende territooriumi piirides. Siber oli vallutatud väga kiiresti. 1586. aastal rajati khaan Kutšumi riigi pealinna Tšingi-Turo varemetele Tjumeni kindlus. 62 järgmise aastaga jõudsid Tomski kasakad Ohhoota mere äärde, kuid edasi põhja ei suutnud nad tungida. Kolõma jõe alamjooks jäi aastakümneteks piirijõeks. Tšuktšide vastupanu oli väga tugev. Kui sõda oli kestnud peaaegu sama kaua kui terve Siberi vallutamine, oli Katariina II sunnitud järele andma Senati taotlusele ja Tšuktšimaa vallutamisest loobuma. 1771. aastal Anadõri kindlus lammutati ja 1778. aastal suudeti lõpuks sõlmida rahu, mida kumbki pool enam ei rikkunud. Peterburist tuli korraldus 
valmistada riigivapid ja saata need tšuktšidele, et tšuktšid riputaksid need oma rannikul puude külge ja näitaksid neid laevadelt maale tulnutele, et teadustada maade kuulumist Vene impeeriumile.

Sellele aitas kaasa muidugi ka asjaolu, et keegi ei teadnud täpselt, kui suur tšuktšide territoorium oli ja kui palju inimesi seal elab. Tšuktšid vange ei vahetanud ja kõik vallutajad tapeti, seega puudus igasugune teave nende kohta. Tšuktše ei suudetud ristida tsaariajal ega täielikult kodustada nõukogude ajal. Mis toimub seal praegu, seda võime ainult oletada.

Minu Tšuktšimaal olles olid ohverdamised veel üks osa minu põhjapõdrakasvatusbrigaadi igapäevaelust, et leevendada halbade vaimude mõju ja meelitada ligi häid vaime.

Tšuktšide tähistaevas on seotud nende põhielatusala põhjapõdrakasvatusega. Paljudel juhtudel ongi antud tähtedele põhjapõtrade või neid karjatavate või jahtivate meeste seotud nimed. On tähekujusid, mille kohta käivate müütide algkodu võib leida inimese migratsiooniteelt läbi Euraasia või veel varasemalt ühiselt kodumaalt.

Tšuktšide uskumuste hulgast võib kindlasti leida andmeid, mis valgustaksid ka meie maausu tagamaid. Neid mütoloogiaid ja uskumusi tuleks uurida enne kui hilja, sest tegemist on väljasureva rahvaga ning koos tšuktšidega kaob nende kultuur.

\section{Kommentaar}

${ }^{1}$ Tanygtan tähendab korjaki keeles 'võõras, vaenlane'. Arvatavasti on tšuktši keeles sõnal sama tähendus (Bogoraz-Tan 1934: 3). 1971. aastal kasutati seda lühemat sõna tanyg muulaste, eelkõige venelaste kohta või kui taheti kellegi väga halvasti ütelda. Ka meid nimetati esialgu, kui alles lennuki pealt tulime, tanygideks, kuid hiljem öeldi meie kohta yanki. Vladimir Bogoraz-Tan (1934: 8) väitel tähendabki tanyg venelast.

\section{Kirjandus}

Bogoraz-Tan 1934 = Богораз-Тан, Владимир. Чукчи I. Ленинград: Изд-во главсевморпути.

Bogoraz-Tan 1939 = Богораз-Тан, Владимир. Чукчи II: Религия. Ленинград: Изд-во главсевморпути. 


\section{Ülo Siimets}

Kulmar, Tarmo 2004. Inti Raymi ehk päikesepüha - Kolumbuse-eelse Peruu inkade suurimaid usupühi. Mäetagused: Hüperajakiri 2004, lk 8190 (http://haldjas.folklore.ee/tagused/nr24/kulmar.pdf - 23. märts 2005).

Kuperjanov, Andres 2003. Eesti taevas: Uskumusi ja tõlgendusi. Tartu: A. Kuperjanov.

McKenzie, Michael \& Prime, Richard \& George, Lisa \& Danning, Ray 2002. Mütoloogiad kogu maailmast: Eri rahvaste mütoloogilised uskumused ja traditsioonid. Tallinn: Avita.

Ó hÓgáin, Daíthí 2004. Kujund kui narratiivi allikas iiri rahvajuttudes. Mäetagused: Hüperajakiri 24, lk 151-169 (http://haldjas.folklore.ee/tagused/nr24/iirijutt.pdf - 23. märts 2005).

Siimets, Ülo 1999. Tšuktšid II. Mäetagused: Hüperajakiri 12, lk 130-137 (http://www.folklore.ee/tagused/nr12/tsukts.htm - 11. mai 2005).

Siimets, Ülo 2003. Tšuktšimaa legendid. Mäetagused: Hüperajakiri 21, lk 231-245 (http://www.folklore.ee/tagused/nr21/legendid.pdf - 11. mai 2005). 